\title{
Peran Kelompok Tani dan Persepsi Petani terhadap Penerapan Budidaya Padi Organik di Kabupaten Jember
}

\section{Role of Farmers 'Groups and Farmers' Perception in Promoting Its Members against Application of Organic Rice Cultivation in District of Jember}

\author{
Syamsul Hadi ${ }^{1}$, Arief Noor Akhmadi ${ }^{2}$, dan Henik Prayuginingsih ${ }^{1}$ \\ ${ }^{1}$ Dosen Faperta Universitas Muhammadiyah Jember, Jember \\ ${ }^{2}$ Dosen FKIP Universitas Muhammadiyah Jember, Jember
}

\begin{abstract}
Farmers in Jember regency have a weak awareness to shift from non-organic farming to organic farming. They are still complacent with the system of application of agricultural technology that is fast and easy. Whereas it has been socialized by the extensionists that the productivity of land with organic system is higher, production costs tend to be lower and output prices are more competitive in the market. The existence of farmer groups also does not give much meaning to the level of participation of its members. Therefore, the purpose of this research is 1) to analyze the role of farmer groups in encouraging the participation of their members towards the application of organic rice cultivation, and 2) to analyze the influence of farmers perceptions about the assurance of the price of organic rice products on the level of farmers' participation. Used descriptive research method quantitative and qualitative through survey technique. Used descriptive and scoring analysis via Likert scale approach and simple linear regression. The results reveal that the role of farmer groups is quite successful in encouraging members to implement organic farming systems with the following arguments: 1) Lack of knowledge and role of farmer groups in giving information related to organic farming (44\%); 2) Low level of farmer awareness, impatient and (12\%), 3) Lack of information related to organic farming systems from local PPL (24\%); and 4) Market guarantee of organic products has not yet convinced farmers (20\%). The perception factor of farmer to product price guarantee have real effect to farmer participation level in the application of organic rice cultivation.
\end{abstract}

Keywords: Role of Farmer Group, Organic Rice Cultivation, Farmer perception

\begin{abstract}
Abstrak
Petani di Kabupaten Jember selama ini masih memiliki kesadaran yang lemah untuk bergeser dari pertanian non organik menuju pertanian organik. Mereka masih terlena dengan sistem penerapan teknologi pertanian yang serba cepat dan mudah. Padahal telah disosialisasikan oleh para penyuluh bahwa produktivitas lahan dengan sistem organik semakin tinggi, biaya produksi cenderung lebih rendah dan harga output lebih bersaing di pasar. Keberadaan kelompok tani juga tidak banyak memberikan pengaruh yang berarti terhadap tingkat partisipasi anggotanya. Oleh karena itu, tujuan penelitian ini adalah 1) menganalisis peran kelompok tani dalam mendorong partisipasi anggotanya terhadap penerapan budidaya padi organik, dan 2) Menganalisis pengaruh persepsi petani tentang jaminan harga produk padi organik terhadap tingkat pertisipasi petani. Digunakan metode penelitian deskriptif kuantitatif dan kualitatif melalui teknik survei. Digunakan analisis deskriptif dan skoring melalui pendekatan skala Likert dan regresi linier sederhana. Hasil penelitian mengungkapkan bahwa peran kelompok tani cukup berhasil dalam mendorong anggotanya untuk menerapkan sistem pertanian organik dengan argumentasi sebagai berikut: 1) Kurangnya pengetahuan dan peran kelompok tani dalam memberi informasi terkait organic farming (44\%), 2) Rendahnya tingkat kesadaran petani, kurang sabar dan tidak mau ruwet (12\%), 3) Minimnya informasi terkait sistem pertanian organik dari PPL setempat (24\%), dan 4) Jaminan pasar produk organik belum meyakintan para petani $(20 \%)$. Adapun faktor persepsi petani terhadap jaminan harga produk berpengaruh nyata terhadap tingkat partisipasi petani dalam penerapan budidaya padi organik.
\end{abstract}

Kata kunci: Peran Kelompok tani, Budidaya Padi Organik, Persepsi Petani

\footnotetext{
${ }^{1}$ Korespondensi penulis

E-mail: syamsul.hadi@unmuhjember.ac.id
} 


\section{Pendahuluan}

Petani di Kabupaten Jember selama ini masih memiliki kesadaran yang masih rendah untuk bergeser dari pertanian non organik menuju pertanian organik. Mereka masih terlena dengan sistem penerapan teknologi pertanian yang serba cepat dan mudah dan mengabaikan pentingnya berusahatani yang ramah lingkungan melalui sistem organik yang berkelanjutan. Berbagai argumentasi yang menjadi alasan, yaitu selain belum menjamin adanya sertifikasi bahan organik yang dijual, ongkos produksinya dinilai mahal dan cara penerapannya cukup rumit atau sulit serta belum ada jaminan pemerintah tentang harga produknya.

Dampak penerapan pertanian organik dianggap relatif lama dan sulit dibuktikan dalam waktu cepat selain lembaga pemasaran hasil produksinya juga belum terbentuk sehingga petani merasa kesulitan dalam memasarkannya dalam waktu cepat pula. Padahal telah disosialisasikan oleh para penyuluh bahwa produktivitas lahan dengan sistem organik semakin tinggi meskipun memerlukan masa konversi selama dua tahun, biaya produksi cenderung lebih rendah dan harga output jauh lebih bersaing di pasar. Seiring dengan mengglobalnya organic farming, permintaan pasar sangat tinggi sejalan dengan kesadaran masyarakat akan pentingnya keamanan pangan dan kesehatan, tingkat kesubuan lahan pertanian di Kabupaten Jember mulai rusak bahkan kadar unsur hara $<2 \%$ (Minimal $\geq 3 \%$ ) dan tingkat produktivitas lahan semakin rendah, maka sudah saatnya petani bergeser menuju pertanian organik (Hadi, et al., 2017).

Gagasan di atas sesuai dengan pendapat Tandisau dan Herniwati (2009 dan 2011) bahwa pertanian organik merupakan cara yang tepat dalam rangka mengatasi dampak negatif teknologi modern, sehingga pembangunan pertanian dapat terus berjalan secara berkelanjutan, masyarakat aman, damai dan sejahtera. Pendapat tersebut diperkuat oleh hasil penelitian Santoso, Hartono dan Nuswantara (2012) di Kecamatan Sambirejo Kabupaten Sragen bahwa produktivitas padi organik lebih tinggi $(7,4$ ton/ha) dibandingkan dengan padi non organik (6,5 ton/ha). Pendapat ini sesuai dengan definisi pertanian organik menurut Mc. Deeck (2007) yaitu sistem manajemen produksi terpadu yang menghindari penggunaan pupuk buatan, pestisida dan hasil rekayasa genetik, menekan pencemaran udara, tanah, dan air. Di sisi lain, pertanian organik meningkatkan kesehatan dan produktivitas di antara flora, fauna dan manusia.

Sejalan dengan fenomena di atas, maka peluang pertanian organik cukup besar di daerah Kabupaten Jember. Hal ini ditandai oleh good will Pemerintah Kabupaten Jember pada tahun 2010 telah menggagas program desa organik dengan melibatkan segenap stake holders yang ada. Program desa organik itu dilakukan karena kondisi lahan pertanian sudah dianggap cukup mengkhawatirkaan. Berdasarkan data di Dinas Pertanian Kabupaten Jember (2012) bahwa unsur hara organik yang terkandung dalam tanah sudah berada di bawah $2 \%$. Padahal idealnya lahan pertanian bisa tergolong subur jika unsur hara oraganiknya di atas 3\%. Hal ini disebabkan penggunaan pupuk non-organik atau pupuk kimia berlebihan yang selama ini dilakukan petani. Sehingga, kondisi lahan pertanian perlu di suburkan lagi dengan menggunakan pupuk organik. Selain itu, Bupati Jember juga menginstruksikan agar meminimalisir alih fungsi lahan sehingga tidak mengurangi lahan produk-tif di Jember. Keingingan pemerintah tersebut belum cukup jika tidak disertai pula dengan keinginan petani secara bersama-sama dan tentunya wajib didukung oleh peran kelompok tani yang besar dan istiqomah.

Keberadaan kelompok tani di perdesaan idealnya mampu mendorong dan menfasilitasi anggotanya dan petani lainnya untuk beralih pada pertanian organik. 
Namun di beberapa wilayah kecamatan yang sudah ada program percobaan padi organik belum mampu diadopsi oleh sebagian besar petani. Padahal jika kelompok petani memiliki komitmen yang kuat pada pertanian organik tersebut, maka semakin mendorong petani agar mengikutinya dan tidak mustahil petani secara perlahan akan berubah sikap dan mindsite-nya.

Pertanian organik menurut pendapat Mc. Deeck (2007) adalah sistem manajemen produksi terpadu yang menghindari penggunaan pupuk buatan, pestisida dan hasil rekayasa genetik, menekan pencemaran udara, tanah, dan air. Di sisi lain, pertanian organik meningkatkan kesehatan dan produktivi-tas di antara flora, fauna dan manusia. Penggunaan masukan di luar pertanian yang menyebabkan degradasi sumber daya alam tidak dapat dikategorikan sebagai pertanian organik. Sebaliknya, sistem pertanian yang tidak menggu-nakan masukan dari luar, namun mengikuti aturan pertanian organik dapat masuk dalam kelompok pertanian organik, meskipun agroekosistemnya tidak mendapat sertifikasi organik. Adapun definisi menurut Permentan RI Nomor 64 Tahun 2013 adalah Sistem Pertanian Organik adalah sistem manajemen produksi yang holistik untuk meningkatkan dan mengembangkan kesehatan agroekosis-tem, termasuk keragaman hayati, siklus biologi, dan aktivitas biologi tanah. Pertanian organik menekankan penerapan praktekpraktek manajemen yang lebih mengutamakan penggunaan input dari limbah kegiatan budidaya di lahan, dengan mempertimbangkan daya adaptasi terhadap keadaan setempat. Jika memungkinkan hal tersebut dapat dicapai dengan penggunaan budaya, metoda biologi dan mekanik, yang tidak menggunakan bahan sintesis untuk memenuhi kebutuhan khusus dalam sistem.

Filosofi pertanian organik sesung-guhnya merupakan himbauan moral untuk berbuat kebajikan pada lingkungan sumberdaya alam dalam melakukan praktek pertanian dengan mempertim-bangkan 3 (tiga) aspek, yaitu (Musriyah, 2016): 1) Aspek Ekonomi, dalam sistem pertanian organik, selalu mempertim-bangkan efisiensi terhdap penggunaan sumberdaya, efisiensi terhadap penggu-naan bahan input eksternal, meminimal-kan biaya pengobatan dan meningkatkan pendapatan/nilai tambah, 2) Aspek Eko-logi, dalam usahatani organik, selalu di-upayakan semaksimal mungkin meman-faatkan input lokal, meminimalkan polusi dari proses kegiatan produksi, memper-baiki tekstur dan kesuburan tanah, menyeimbangkan keanekaragaman biolo-gi, mengedepankan usahatani berkelanju-tan, konservasi sumberdaya alam dan berupaya menjaga keseimbangan ekosis-tem, dan 3) Aspek Sosial, dalam usahatani organik selalu berupaya me-ningkatkan kepekaan yang lebih baik terhadap lingkungan, penghargaan terhadap budaya lokal, pemenuhan kebu-tuhan produk yang sehat dan aman dikonsumsi, mengutamakan lingkungan kerja yang aman dan sehat serta menjaga keharmonisan sosial di pedesaan.

Departemen Pertanian telah mencanangkan pengembangan pertanian organik dengan slogan 'Go Organik 2010'. Sinergisme aktivitas dan pelaku usaha dapat mempercepat pencapaian tujuan dari "Go Organik 2010" yaitu 'Indonesia sebagai salah satu produsen pangan organik utama dunia'. Pertanian organik dirancang pengembangannya dalam enam tahapan mulai dari tahun 2001 hingga tahun 2010 . Tahapan tersebut adalah adalah sebagai berikut : Tahun 2001 difokuskan pada kegiatan sosialisasi; Tahun 2002 difokuskan pada kegiatan sosialisasi dan pembentukan regulasi; Tahun 2003 difokuskan pada pembentukan regulasi dan bantuan teknis; Tahun 2004 difokuskan pada kegiatan bantuan teknis dan sertifikasi; Tahun 2005 difokuskan pada sertifikasi dan promosi pasar; dan Tahun 2006 - 2010 terbentuk kondisi industrialisasi dan perdagangan. 
Banyak pihak yang merasa pesimis bahwa program tersebut dapat diwujudkan pada Tahun 2010. Dalam rangka mewujudkan Go Organik 2010, hingga saat itu belum ada produk hukum yang mengharuskan pemakaian pupuk organik dalam sektor pertanian. Namun Deptan menyelenggarakan kegiatan Musyawarah Perencanaan Pembangunan Pertanian yang merumuskan bahwa kegiatan pembangunan pertanian periode 2005-2009 dilaksanakan melalui tiga program, yaitu (1) Program peningkatan ketahanan pangan, (2) Program pengembangan agribisnis, dan (3) Program peningkatan kesejahteraan petani. Selanjutnya kementerian pertanian pada tahun 2013 menelurkan Peraturan Menteri Pertanian Nomor: 64/Permentan/OT.140/5/2013 tentang sistem Pertanian Organik pada tanggal 29 Mei 2013 atas dasar pertimbangan bahwa pembangunan pertanian khususnya pertanian organik pada era globalisasi harus mendukung tumbuhnya dunia usaha sehingga mampu menghasilkan produk organik yang memiliki jaminan atas integritas organik yang dihasilkan. Bahwa dengan memiliki jaminan atas integritas organik, maka dapat meningkatkan kepercayaan masyarakat dan sekaligus mendapatkan jaminan atas produk tersebut tanpa mengakibatkan kerugian konsumen.

Pertanian organik didasari pada empat prinsip, yaitu (IFOAM, 2009): prinsip kesehatan, prinsip ekologi, prinsip keadilan, dan prinsip perlindungan. Setiap prinsip dinyatakan melalui suatu pernyataan disertai dengan penjelasannya. Prinsipprinsip ini harus digunakan secara menyeluruh dan dibuat sebagai prinsipprinsip etis yang mengilhami tindakan. Prinsip kesehatan adalah Pertanian organik harus melestarikan dan meningkatkan kesehatan tanah, tanaman, hewan, manusia dan bumi sebagai satu kesatuan dan tak terpisahkan. Prinsip ini menunjukkan bahwa kesehatan tiap individu dan komunitas tak dapat dipisahkan dari kesehatan ekosistem; tanah yang sehat akan menghasilkan tanaman sehat yang dapat mendukung kesehatan hewan dan manusia. Sementara itu, prinsip ekologi adalah pertanian organik harus didasarkan pada sistem dan siklus ekologi kehidupan. Bekerja, meniru dan berusaha memelihara sistem dan siklus ekologi kehidupan. Prinsip ekologi meletakkan pertanian organik dalam sistem ekologi kehidupan, dimana kontek produksi didasarkan pada proses dan daur ulang ekologis.

Selanjutnya prinsip keadilan yang dimaksud adalah pertanian organik harus membangun hubungan yang mampu menjamin keadilan terkait dengan lingkungan dan kesempatan hidup bersama. Keadilan dicirikan dengan kesetaraan, saling menghormati, berkeadilan dan pengelolaan dunia secara bersama, baik antar manusia dan dalam hubungannya dengan makhluk hidup yang lain. Prinsip ini menekankan bahwa mereka yang terlibat dalam pertanian organik harus membangun hubungan yang manusiawi untuk memastikan adanya keadilan bagi semua pihak di segala tingkatan; seperti petani, pekerja, pemroses, penyalur, pedagang dan konsumen. Adapun prinsip perlindungan yang dimaksud adalah Pertanian organik harus dikelola secara hati-hati dan bertanggung jawab untuk melindungi kesehatan dan kesejahteraan generasi sekarang dan mendatang serta lingkungan hidup. Pertanian organik merupakan suatu sistem yang hidup dan dinamis yang menjawab tuntutan dan kondisi yang bersifat internal maupun eksternal. Seiring waktu, pengalaman praktis yang dipadukan dengan kebijakan dan kearifan tradisional menjadi solusi tepat. Pertanian organik harus mampu mencegah terjadinya resiko merugikan dengan menerapkan teknologi tepat guna dan menolak teknologi yang tak dapat diramalkan akibatnya, seperti rekayasa genetika (genetic engineering). Segala keputusan harus mempertimbangkan nilai-nilai dan kebutuhan dari semua aspek yang mungkin dapat terkena dampaknya, 
melalui proses-proses yang transparan dan partisipatif.

Hasil penelitian Nurmala (2011) di Desa Ciburuy dan Desa Cisalada, Kecamatan Cigombong, Kabupaten Bogor menyimpulkan bahwa usahatani padi semi organik lebih layak dijalankan dibandingkan anorganik karena menghasilkan NPV dan gross $\mathrm{B} / \mathrm{C}$ ratio yang lebih tinggi. Total biaya rata-rata per hektar per musim tanam usahatani padi semi organik lebih tinggi dibandingkan usahatani padi anorganik. Pendapatan ratarata dan $\mathrm{R} / \mathrm{C}$ ratio yang dihasilkan bahwa usahatani padi semi organik akan menghasilkan nilai yang lebih besar dibandingkan usahatani padi anorganik.

Selanjutnya hasil penelitian Hindarti, Muhaimin dan Sumarno (2012) di Desa Bumiaji Kota Batu menyimpul-kan bahwa faktor pengalaman dan pendapatan usahatani berpengaruh terhadap keputusan petani apel untuk menerapkan sistem pertanian organik. Sedangkan variabel umur dan pendidikan petani tidak berpengaruh terhadap keputusan petani untuk menerapkan sistem pertanian organik. Demikian pula hasil penelitian Rukka, Buhaerah dan Sunaryo (2006) di Kabupaten Gowa menunjukkan bahwa faktor internal seperti motivasi petani, pengalaman berusahatani dan luas lahan garapan menunjukkan adanya kolerasi nyata pada respon petani terhadap penggunaan pupuk organik pada padi sawah, sedangkan tingkat pendidikan formal tidak memperlihatkan adanya hubungan.

Selanjutnya hasil penelitian Widnyana (2011) di Desa Aan Kecama-tan Banjarangkan Klungkung mengung-kapan bahwa respon petani terhadap kegiatan pendampingan penanaman padi berbasis organik cukup tinggi. Hal ini ditunjukkan dari hasil evaluasi bahwa $100 \%$ dari petani SIT mengetahui dan paham tentang budidaya padi sistem organik, dan mereka sepakat mengem-bangkan sistem budidaya ini di masa mendatang. Sementara hasil penelitian Ediyanto dan Hadi (2015) di Desa Sruni Kecamatan Jenggawah Kabupaten Jember mengungkapkan bahwa rata-rata petani memiliki respon yang tinggi pada sistem pertanian organik meskipun tingkat aplikasinya sebagian besar masih pada level semi organik. Kondisi ini disebabkan karena kelompok tani bersama gapoktannya secara intensif senantiasa memberikan pemahaman akan pentingnya sistem pertanian organik di era saat ini, terlebih di desa tersebut sudah diproduksi pupuk dan pestisida organik (nabati) secara mandiri dan berkelanjutan.

Penerapan sistem pertanian organik pada usahatani padi di Kabupaten Jember secara teknis belum berjalan seperti yang diharapkan. Meskipun sudah ada yang memulai sejak tahun 2008, 2010, dan 2012, namun masih bersifat semi-organik yaitu dengan cara kombinasi aplikasi bahanbahan an organik dan organik dengan porsi yang beragam. Keberadaan kelompok tani juga tidak banyak memberikan pengaruh yang berarti terhadap tingkat partisipasi anggotanya dalam penerapan sistem pertanian organik pada budidaya padi. Oleh karena itu, tujuan penelitian ini adalah 1) menganalisis peran kelompok tani dalam mendorong partisipasi anggotanya terhadap penerapan budidaya padi organik, dan 2) Menganalisis pengaruh persepsi petani tentang jaminan harga produk padi organik terhadap tingkat pertisipasi petani.

\section{Metode Penelitian}

\section{Jenis, Waktu dan Lokasi Penelitian}

Jenis penelitian ini adalah penelitian deskriptif kuantatif dan kualitatif, sementara metode yang digunakan dalam penelitian ini adalah metode survei (Singarimbun, 1987). Dipilihnya metode survei karena jumlah populasi sasaran jenis kegiatan terlampau banyak dan tersebar di beberapa wilayah kecamatan. Penelitian ini dilakukan pada tahun 2017 dilaksanakan di Kabupaten Jember secara purposive sampling yang meliputi di Kecamatan 
Sumberjambe, Patrang, Panti, Jenggawah, Tempurejo, Umbulsari, dan Tanggul. atas pertimbangan bahwa di wilayah tersebut sebagian kelompok tani telah menerapkan sistem pertanian organik sejak tahun 2012 pada usahatani padi meskipun masih bersifat semi-organik.

\section{Teknik Pengumpulan Data}

Teknik pengumpulan data primer dilakukan dengan cara gabungan beberapa teknik pengumpulan data yang saling melengkapi yaitu meliputi : FGD dan Indepth Interview. Adapun penggalian data sekunder yang meliputi Manteri Pertanian Kecamatan, BPP-PPL, dan Pamong Tani serta Dinas Pertanian Kabupaten Jember dilakukan secara convenience sampling sesuai dengan kebutuhan penelitian. Selanjutnya populasi penelitian ini terdiri dari pengurus kelompok tani dan anggota kelompok tani yang berusahatani padi organik yang ditentukan sejumlah sampel penelitian secara Disprobability sampling dengan teknik Quota sampling per kelompok tani (Singarimbun, 1987).

\section{Teknik Analisis Data}

Guna mengetahui sejauhmana peran kelompok tani dalam mendorong tingkat partisipasi anggotanya untuk menerapkan sistem pertanian organik pada usahatani padinya di daerah penelitian dianalisis dengan deskriptif dan skoring dengan pendekatan skala likert dengan tiga variabel utama penilaian, yaitu partisipasi petani pada perencanaan, pelaksanaan, dan evalusi partisipatif. Adapun jumlah instrumen pada maisng-masing variabel utama penilaian terdiri dari delapan, lima dan enam, dimana tiap instrumen terdapat 3 macam rangking (skor), yaitu: 3, 2, dan 1. Oleh karena itu, kriteria keputusannya adalah sebagai berikut: 1) jika rata-rata total skor $\leq 19$ tingkat partisipasi Rendah, antara $20-38$ tingkat partisipasi Sedang, dan antara 39 57 tingkat partisipasi Tinggi.

Guna menganalisis pengaruh faktor persepsi petani tentang adanya jaminan harga produk padi organik terhadap tingkat partisipasi petani dalam penerapan budidaya padi organik di daerah penelitian, maka akan digunakan alat analisis regresi linier dengan persamaan sebagai berikut:

$$
\mathrm{Y}=\alpha+\beta \mathrm{X}_{\mathrm{i}}+\varepsilon
$$

Keterangan:

$\mathrm{Y}=$ Tingkat Partisipasi Petani dalam budidaya padi organik (Rata-rata Total Skor)

$\alpha=$ konstanta, $\beta=$ koefisien regresi

$\mathrm{X}_{\mathrm{i}}=$ Persepsi Petani tentang jaminan harga produk padi organik (Rata-rata Total Skor)

$\varepsilon \quad=$ Galat

Selanjutnya untuk menguji tingkat keberartian pengaruh variabel independent terhadap variabel dependent, maka diajukan rumusan hipotesis sebagai berikut:

$\mathrm{H}_{0}: \beta_{\mathrm{i}}=0$ (Tolak Ha atau terima $\left.\mathrm{H}_{0}\right)$, berarti berpengaruh tidak nyata

$\mathrm{H}_{\mathrm{a}}: \beta_{\mathrm{i}} \neq 0\left(\right.$ Tolak $\mathrm{H}_{0}$ atau terima $\left.\mathrm{H}_{\mathrm{a}}\right)$, berarti berpengaruh nyata

\section{Hasil dan Pembahasan}

\section{Peran Kelompok Tani terhadap Tingkat Partisipasi Petani dalam Budidaya Padi Organik}

Kelembagaan merupakan basis terbentuknya modal sosial yang dapat menfasilitasi kerjasama dalam aktivitas agribisnis padi organik. Dukungan kelembagaan dalam pengembangan sistem pertanian organik mempunyai peranan penting dalam setiap aktivitas masingmasing subsistem agribisnis. Modal sosial petani yang meliputi jaringan kerjasama, saling percaya dalam kerjasama, dan norma kerjasama dalam sistem pertanian organik akan mempengaruhi keberhasilan agribisnis. Keberadaan kelembagaan petani seperti kelompok tani dapat memberikan motivasi pada anggotanya dalam mengadopsi 
teknologi baru. Kelompok tani dipandang sebagai suatu unit kajian yang memiliki jiwanya sendiri, terdapat empat aspek yang bisa dipelajari untuk mengetahui motivasi kelembagaan yaitu sejarah kelembagaan (institutional history), misi yang diembannya, kultur yang menjadi pegangan dalam bersikap dan berperilaku anggotanya, serta pola penghargaan yang dianut (incentive schemes) (Nuraini, et al., 2016).

Suatu fakta sosial adalah fakta historik, sejarah perjalanan kelembagaan merupakan pintu masuk yang baik untuk mengenali secara cepat aspek aspek kelembagaan yang lain. kinerja kelembagaan (institutional performance), terdiri dari: keefektifan kelembagaan dalam mencapai tujuantujuannya, efisiensi penggunaan sumber daya, dan keberlanjutan kelembagaan berinteraksi dengan para kelompok kepentingan di luarnya. Hal ini menunjukkan bahwa kalkulasi secara ekonomi merupakan prinsip yang menjadi latar belakangnya. Adapun analisis kelembagaan dalam bidang pertanian adalah analisis yang ditujukan untuk memperoleh deskripsi mengenai suatu fenomena sosial ekonomi pertanian yang berkaitan dengan hubungan antara dua atau lebih pelaku interaksi sosial ekonomi, mencakup dinamika aturan-aturan yang berlaku dan disepakati bersama oleh para pelaku interaksi, disertai dengan analisis mengenai hasil akhir yang diperoleh dari interaksi yang terjadi. Dalam batas-batas tertentu analisis kelembagaan dapat berlaku umum di berbagai wilayah dan keadaan, namun dalam banyak hal aspek lokalitas dan permasalahan spesifik harus selalu memperoleh penekanan (Syahyuti, 2002 dalam Nuraini, et al., 2016).

Tabel 1 di bawah menggambarkan peran kelompok tani dalam mendorong anggotanya untuk menerapkan budidaya padi organik pada lahan usahataninya pada beberapa bentuk kegiatan. Kegiatan terbanyak $(52 \%)$ adalah berupa penyuluhan tentang budidaya padi organik dan sistem pertanian berkelanjutan serta praktek langsung (Memberikan contoh riil pada organik) pada anggotanya. Kegiatan ini dilakukan oleh kelompok tani berdasarkan inisiatif lembaga berdasarkan Peraturan Menteri Pertanian Nomor: 64/Permentan/OT.140/5/2013 BAB I Pasal 2 dan 3 Ayat (1) dan (3) huruf (e) dan (f), dan Buku Petunjuk Teknis Pengembanga Desa Organik Padi Tahun 2016 yang diterbitkan oleh Direktorat Jenderal Tanaman Pangan - Kementerian Pertanian. Berdasarkan produk hukum itu, Kabupaten Jember menjadi salah satu lokasi sasaran diantara 16 Kabupaten/Kota di Propinsi Jawa Timur pada tahun 2016 dimana target areal tanam seluas 40 hektar. Selain itu, bentuk kegiatan peran kelompok tani adalah sebanyak $12 \%$ berupa pertemuan rutin dalam 1 - 2 minggu satu kali dan diskusi dengan menghadirkan PPL, Mendorong lahan milik pribadi ketua poktan untuk demplot padi organik 4\%, Penyaluran bantuan sarana pupuk organik (pupuk urine sapi dan kompos) 28\% dan sering mendatangkan narasumber untuk menambah wawasan petani setiap satu bulan sekali dari malang dan bandung sebanyak 4\%. Pada pertemuan rutin beberapa hal yang dibahas untuk pemecahan masalah kebuntuan anggota kelompok dalam menerapkan sistem pertanian organik sejalan dengan dinamika kendalanya. Eksistensi dan peranan kelompok tani tersebut sangat penting artinya bagi sebuah komunitas yang memiliki masalah dan tujuan bersama. Fenomena ini sejalan dengan hasil riset Permana (2016) tentang peran kelompok tani dalam budidaya sayuran organik di Desa Batur Kecamatan Getasan Kabupaten Semarang yang mengungkapkan bahwa dalam usaha budidaya sayuran organik memerlukan peran kelompok tani pada setiap tahapan proses produksi dan pemasaran produk. Kelompok tani memberikan solusi permasalahan usaha budidaya sayuran organik pada setiap pertemuan rutin antar anggota kelompok tani. Petani yang tidak bergabung dalam 
Tabel 1. Peran Kelompok Tani dalam Mendorong Anggotanya untuk Menerapkan SPO Menurut Persespi Pengusus di Kabupaten Jember

\begin{tabular}{|c|c|c|c|c|}
\hline No & Uraian Peran Kelompok tani & Bentuk Kegiatan Peran & $\begin{array}{l}\text { Jumlah } \\
\text { (Org) }\end{array}$ & $\%$ \\
\hline \multirow{5}{*}{1} & \multirow{5}{*}{$\begin{array}{l}\text { Upaya yang dilakukan } \\
\text { kelompok tani dalam untuk } \\
\text { Mendorong anggotanya } \\
\text { menerapkan sistem pertanian } \\
\text { organik }\end{array}$} & $\begin{array}{l}\text { Penyuluhan tentang budidaya padi organik } \\
\text { dan sistem pertanian berkelanjutan dan } \\
\text { praktek langsung (Memberikan contoh riil } \\
\text { pada organik) }\end{array}$ & 13 & 52.00 \\
\hline & & $\begin{array}{l}\text { Mengadakan pertemuan rutin dalam } 1-2 \\
\text { minggu satu kali dan diskusi dengan } \\
\text { menghadirkan PPL (narasumber) }\end{array}$ & 3 & 12.00 \\
\hline & & $\begin{array}{l}\text { Mendorong lahan milik pribadi ketua poktan } \\
\text { untuk demplot padi organik }\end{array}$ & 1 & 4.00 \\
\hline & & $\begin{array}{l}\text { Penyaluran bantuan sarana pupuk organik } \\
\text { (pupuk urine sapi dan kompos) }\end{array}$ & 7 & 28.00 \\
\hline & & $\begin{array}{l}\text { Sering mendatangkan narasumber untuk } \\
\text { menambah wawasan petani setiap satu bulan } \\
\text { sekali dari malang dan bandung }\end{array}$ & 1 & 4.00 \\
\hline \multirow{3}{*}{2} & \multirow{3}{*}{$\begin{array}{l}\text { Penilaian terhadap tingkat } \\
\text { keberhasilan peran kelompok } \\
\text { tani dalam mendorong } \\
\text { anggotanya untuk berusahatani } \\
\text { secara organik, }\end{array}$} & $0 \%$ s.d $30 \%$ & 3 & 12.00 \\
\hline & & $31 \%$ s.d $60 \%$ & 13 & 52.00 \\
\hline & & $61 \%-90 \%$ & 9 & 36.00 \\
\hline \multirow{6}{*}{3} & \multirow{6}{*}{$\begin{array}{l}\text { Faktor penyebab kegagalan } \\
\text { peran kelompok tani dalam } \\
\text { penerapan sistem pertanian } \\
\text { organik (SPO) }\end{array}$} & $\begin{array}{l}\text { Minimnya informasi terkait sistem pertanian } \\
\text { organik dari PPL setempat dan bukti yang } \\
\text { nyata }\end{array}$ & 6 & 24.00 \\
\hline & & $\begin{array}{l}\text { Rendahnya tingkat kesadaran petani, kurang } \\
\text { sabar dan tidak mau ruwet }\end{array}$ & 3 & 12.00 \\
\hline & & $\begin{array}{l}\text { Kurangnya pengetahuan dan peran serta } \\
\text { penyuluh kelompok tani dalam memberi } \\
\text { informasi terkait SPO }\end{array}$ & 4 & 16.00 \\
\hline & & $\begin{array}{l}\text { Petani masih kurang menerima fasilitas dari } \\
\text { pemerintah soal SPO }\end{array}$ & 5 & 20.00 \\
\hline & & $\begin{array}{l}\text { Letak Demplot kurang tepat (masih } \\
\text { terkontaminasi dengan konvensional }\end{array}$ & 2 & 8.00 \\
\hline & & $\begin{array}{l}\text { Jaminan pasar produk organik belum } \\
\text { meyakintan para petani }\end{array}$ & 5 & 20.00 \\
\hline
\end{tabular}

Sumber: Data Primer Diolah Tahun 2017

kelompok akan kesulitan dalam pemasaran produk dan harga jual produk sayuran organik dipermainkan oleh pasar.

Tabel 1 di atas juga menunjukkan tingkat keberhasilan peran kelompok tani dalam mendorong anggotanya menerapkan sistem pertanian organik pada budidaya padi. Menurut penilaian anggotanya bahwa ratarata tingkat keberhasilan kelompok tani mencapai $57,33 \%$ dimana sebagian besar $(52 \%)$ responden menyatakan cukup berhasil, sebagian lagi (36\%) menyatakan sudah berhasil dan sebagian lainnya menyatakan gagal. Adapun yang responden menyatakan cukup berhasil - sudah berhasil beralasan karena jumlah petani yang berpartisipasi menerapkan budidaya padi organik dari musim ke musim semakin bertambah, produksinya dari musim ke musim semakin meningkat meskipun di awal-awal penerapannya sempat turun drastis, penyediaan sarana produksi berbasis bahan organik cukup terjaungkau baik tempat maupun harganya, dan keuntungan usahatani semakin tinggi.

Sementara itu, responden yang menyatakan peran kelompok tani mengalami kegagalan dalam mendorong anggotanya terhadap penerapan sistem pertanian organik (SPO) memiliki argumentasi sebagai berikut: 1) 
Minim-nya informasi terkait sistem pertanian organik dari PPL setempat dan bukti yang nyata $(24 \%)$, 2) Rendahnya tingkat kesadaran petani, kurang sabar dan tidak mau ruwet $(12 \%), 3)$ Kurangnya pengetahuan dan peran serta penyuluh kelompok tani dalam memberi informasi terkait SPO $(16 \%)$, 4) Petani masih kurang menerima fasilitas dari pemerintah soal SPO (20\%), 5) Letak Demplot kurang tepat (masih terkontami-nasi dengan konvensional (8\%), dan 6) Jaminan pasar produk organik belum meyakintan para petani $(20 \%)$. Berdasarkan kondisi tersebut maka dapat ditegaskan bahwa kelompok tani di daearah penelitian memiliki memiliki peranan yang kurang kuat dalam mendorong anggotanya menerapkan sistem pertanian organik.

Sementara hasil riset Nuryanti dan Swastika (2011) mengungkapkan bahwa pada umumnya program-program ban-tuan pemerintah seperti: penyaluran pupuk bersubsidi, penyuluhan teknologi pertanian, kredit usahatani bersubsidi, dan program-program lain disalurkan melalui kelompok tani atau gabungan kelompok tani (Gapoktan). Petani yang ingin mendapat teknologi baru dan berbagai program bantuan pemerintah harus menjadi anggota kelompok atau anggota Gapoktan. Dengan demikian, peran kelompok tani tidak hanya sebagai media untuk menyalurkan bantuanbantuan pemerintah, tetapi juga sebagai agen penerapan teknologi baru. Beberapa alasan responden mengapa kelompok petani di daerah penelitian ini mengalami kegagalan antara lain dise-babkan proses pendampingan kelom-pok tani kurang intensif dalam menstransfer informasi tentang teknologi, peluang pasar, dan harga output yang berimplikasi terhadap tingkat partisipasi anggotanya dalam sistem pertanian organik kurang signifikan.

Sebagai pembanding penilaian anggota kelompok tani terhadap peran kelompoknya dalam menerapkan budi-daya padi organik, maka Tabel 2 di bawah menggambarkan peran kelompok tani menurut persespsi pengurus lembaga. Kelompok tani dalam mendorong anggotanya menerapkan sistem pertanian organik adalah tidak berbeda dengan persepsi anggota kelompok tani. Ada tambahan upaya yang dilakukan kelom-pok tani selain yang dinilai anggotanya, yaitu mendorong lahan milik pribadi ketua poktan untuk demplot padi organik yaitu sebanyak 10\%. Sebagian besar pengurus kelompok tani terutama ketua, sektretaris, dan bendahara dipaksa untuk membuat demplot sebagai percontohan sekaligus pembuktian terhadap sesuatu dorongan yang dilakukan kelompok kepada anggotanya. Namun hanya beberapa pengurus saja yang mau dan mampu untuk melakukan upaya yang beresiko tinggi untuk sebuah awal penerapan sistem pertanian organik. Perbedaan penilain lainnya adalah pada tingkat keberhasilan peran kelompok tani antara pengurus dengan anggotanya, dimana menurut anggota kelompok tani tingkat keberhasilan peran lembaga rata-rata $57,33 \%$, sedangkan menurut pengurus lembaga hanya mencapai $53,20 \%$. Namun demikian kondisi perbedaan penilaian ini cukup kontradiktif meskipun setelah diuji secara statistik pada taraf nyata $\alpha=10 \%$ hasilnya tidak signifikan yang ditunjukkan nilai t-hitung $(0,680)<$ t-statistik (1,32). Selanjutnya faktor kegagalan kelompok tani dalam mendorong anggotanya dalam menerapkan SPO relatif sama dengan penilaian menurut persepsi anggota. Ada perbedaan diantaranya penilaian keduanya yaitu antara lain faktor 1) jaminan pasar produk organik belum meyakinkan para para petani $(20 \%)$, dan faktor yang paling dominan adalah para petani masih malas untuk mencoba karena takut gagal, dan kemampuan teknis para petani dalam mengelola SPO rendah $(26,67 \%)$.

Namun secara obyektif dapat dijelaskan bahwa kedua faktor tersebut sesungguhnya merupakan indikasi kegagalan kelompok 
Tabel 2. Peran Kelompok Tani dalam Mendorong Anggotanya untuk Menerapkan SPO Menurut Persespi Anggota di Kabupaten Jember

\begin{tabular}{|c|c|c|c|c|}
\hline No & Uraian Peran Kelompok Tani & Bentuk Kegiatan Peran & $\begin{array}{l}\text { Jumlah } \\
\text { (Org) }\end{array}$ & $\%$ \\
\hline \multirow{5}{*}{1} & \multirow{5}{*}{$\begin{array}{l}\text { Upaya yang dilakukan untuk } \\
\text { kelompok tani dalam } \\
\text { mendorong anggotanya } \\
\text { menerapkan sistem pertanian } \\
\text { organik }\end{array}$} & $\begin{array}{l}\text { Mengadakan penyuluhan tentang budidaya padi } \\
\text { organik dan sistem pertanian berkelanjutan dan } \\
\text { praktek langsung (Memberikan contoh riil pada } \\
\text { organik) }\end{array}$ & 17 & 56,67 \\
\hline & & $\begin{array}{l}\text { Mengadakan pertemuan rutin dalam } 1-2 \text { minggu } \\
\text { satu kali dan diskusi dengan menghadirkan PPL } \\
\text { (narasumber) }\end{array}$ & 2 & 6,67 \\
\hline & & $\begin{array}{l}\text { Mendorong lahan milik pribadi ketua poktan untuk } \\
\text { demplot padi organik }\end{array}$ & 3 & 10,00 \\
\hline & & $\begin{array}{l}\text { Penyaluran bantuan sarana pupuk organik (pupuk } \\
\text { urine sapi dan kompos) }\end{array}$ & 6 & 20,00 \\
\hline & & $\begin{array}{l}\text { Sering mendatangkan narasumber untuk menambah } \\
\text { wawasan petani setiap satu bulan sekali dari } \\
\text { malang dan bandung }\end{array}$ & 2 & 6,67 \\
\hline \multirow{3}{*}{2} & \multirow{3}{*}{$\begin{array}{l}\text { Penilaian terhadap tingkat } \\
\text { keberhasilan peran kelompok } \\
\text { tani dalam mendorong } \\
\text { anggotanya untuk berusahatani } \\
\text { secara organik, }\end{array}$} & $0 \%$ s.d $30 \%$ & 5 & 16,67 \\
\hline & & $31 \%$ s.d $60 \%$ & 12 & 40,00 \\
\hline & & $61 \%-90 \%$ & 13 & 43,33 \\
\hline \multirow{7}{*}{3} & \multirow{7}{*}{$\begin{array}{l}\text { Faktor penyebab kegagalan } \\
\text { peran kelompok tani dalam } \\
\text { penerapan sistem pertanian } \\
\text { organik (SPO) }\end{array}$} & $\begin{array}{l}\text { Tidak adanya hal yang dapat mendorong petani } \\
\text { untuk sama-sama berusaha membudidayakan } \\
\text { sistem padi organik dan antar anggota kelompok } \\
\text { tidak satu visi dan tujuan yang sama }\end{array}$ & 2 & 6,67 \\
\hline & & $\begin{array}{l}\text { Sosialisasi dan contoh praktek yang diberikan } \\
\text { kurang dipahami oleh kelompok tani }\end{array}$ & 3 & 10,00 \\
\hline & & $\begin{array}{l}\text { Kurangnya pengetahuan dan peran serta penyuluh } \\
\text { kelompok tani dalam memberi informasi terkait } \\
\text { SPO }\end{array}$ & 3 & 10,00 \\
\hline & & $\begin{array}{l}\text { Petani masih kurang menerima fasilitas dari } \\
\text { pemerintah soal SPO }\end{array}$ & 5 & 16,67 \\
\hline & & Intensitas penyuluhan pendampingan masih minim & 3 & 10,00 \\
\hline & & $\begin{array}{l}\text { Jaminan pasar produk organik belum meyakintan } \\
\text { para para petani }\end{array}$ & 6 & 20,00 \\
\hline & & $\begin{array}{l}\text { Para petani masih malas untuk mencoba karena } \\
\text { takut gagal, dan kemampuan teknis para petani } \\
\text { dalam mengelola SPO rendah, }\end{array}$ & 8 & 26,67 \\
\hline
\end{tabular}

Sumber: Data Primer Diolah Tahun 2017

tani dalam mengintervensi anggotanya dalam menerapkan SPO. Hal ini disebabkan kelompok tani kurang intensif dalam melakukan sosialisasi untuk memberikan pemahaman SPO kelebihan dan kekurangganya kepada anggotanya, pendampingan dan fasilitas yang diberikan kurang optimal, serta kapasitas dan peran kelembagaan petani masih relatif rendah (lemah). Selain itu, tidak semua pengurus anggota kelompok tani menerapkan budidaya padi organik meskipun bersifat semi-organik, mereka masih banyak yang menerapkan sistem konvensional. Akibatnya para anggota kurang responsif dan partisipatif untuk menerapkan budidaya padi organik karena tidak ada teladan.
Pada dasarnya para petani sangat siap menerima sistem pertanian berkelanju-tan karena input yang digunakan telah tersedia di lingkungan alam sekitarnya. Dengan pengetahuan tradisional yang dimiliki, para petani perlu diberdayakan sehingga memiliki pengetahuan yang meningkat tentang pertanian berkelanjutan, serta memahami peluang dan tuntutan pasar yang menghendaki produk berkualitas dan ramah lingkungan. Dengan demikian, para petani dapat menghasilkan produk pertanian bernilai ekonomis tinggi sekaligus dapat menjaga kelestarian fungsi lingkungan (Safaruddin, 2011 dalam Sitopu, et al., 2014). Keberhasilan pembangunan pertanian tidak 
bisa terlepas dari partisipasi masyarakat tani. Oleh karena itu, dalam pelaksanaan pembangunan partisipasi masyarakat merupakan hal yang sangat mempengaruhi keberhasilan proses pembangunan itu sendiri (Murtiyanto, 2011).

Pada Tabel 3 di bawah dapat digambarkan bahwa secara keseluruhan dampak peran kelompok tani terhadap tingkat partisipasi petani dalam budidaya padi organik tergolong sedang $(37,89)$ dengan kisaran 1 - 57 atau secara persentase mencapai $65,40 \%$. Namun jika diuraikan pada aspek partisipasi, maka tingkat partisipasi pada perencanaan paling tinggi dibandingkan dengan aspek pelaksanaan dan evaluasi. Kondisi ini di sebabkan pendampingan kelompok tani selama proses penerapan SPO pada usahatani padinya kurang optimal selain faktor motivasi petani yang relatif kurang kuat. Terlebih pada aspek evaluasi, responden petani tingkat partisipasinya semakin menurun dibandingnya dua aspek sebelumnya. Hal ini disebabkan karena hasil produksinya lebih menurun dibandingkan dengan sebelumnya (padi konvensional), harga produksi tidak sesuai harapan (ekspektasi) dan menurunnya kepercayaan petani terhadap jaminan pemerintah terhadap harga produk dan pasar.

Tabel 3. Tingkat Partisipasi Responden Petani terhadap Penerapan SPO pada Budidaya Padi di Kabupaten Jember 2017

\begin{tabular}{clc}
\hline No & \multicolumn{1}{c}{ Indikator } & Rata-rata Nilai Skor $=\mathbf{\%}$ \\
\hline 1 & Perencanaan & $18,17$ (Kisaran: $1-24)=75,69 \%$ \\
2 & Pelaksanaan & $9,87$ (Kisaran: $1-15)=65,78 \%$ \\
3 & Evaluasi Partisipatif & $9,85$ (Kisaran $: 1-18)=54,74 \%$ \\
\hline & Jumlah Total Skor & $\mathbf{3 7 , 8 9}($ Kisaran: $\mathbf{1}-\mathbf{5 7})=\mathbf{6 5 , 4 0 \%}$ \\
\hline
\end{tabular}

Sumber: Data Primer Diolah Tahun 2017.

Kondisi tingkat partisipasi petani terhadap sistem pertanian organik pada usahatani padi sebagaimana pada Tabel 3 di atas, ternyata masih lebih baik dibandingkan dengan hasil penelitian Sitopu et al., (2014) justru tingkat partisipasinya relatif lebih rendah dibandingkan dengan di daerah penelitian ini meskipun menggunakan parameter yang berbeda, dimana tingkat partisipasi petani dalam penerapan usahatani padi organik di Desa Lubuk Bayas adalah sedang, dengan skor tingkat partisipasi petani adalah 17,53. Kondisi ini dapat menjelaskan bahwa peluang penerapan budidaya padi organik di daerah penelitian prospektif untuk diusahakan. Hal ini tidak lepas dari hasil penelitian Hadi et al, (2017) berdasarkan pemahaman dan keyakinan petani di daerah penelitian tentang kelebihan usahatani padi organik dibandingkan konvensional adalah nyata secara ekonomis lebih menguntungkan $(70,67 \%)$, dan teknologi serta pemasarannya dengan harga yang lebih tinggi dibandingkan harga produk dengan sistem konvensional (77,33\%). Menurut logika berfikir dan teori yang benar bahwa jika persepsi peluang pasar semakin tinggi, maka respon petani akan semakin kuat/tinggi sebagaimana hasil penelitian Rukka dkk (2006) di Kabupaten Gowa.

\section{Analisis Pengaruh Faktor Persepsi Petani tentang Jaminan Harga Produk Padi Organik terhadap Tingkat Partisipasi dalam Penerapan Budidaya Padi Organik}

Hasil analisis regresi sederhana sebagaimana yang ditunjukkan pada Tabel 4 di bawah dapat diungkapkan bahwa faktor persepsi petani tentang jaminan harga produk padi organik berpengaruh nyata terhadap tingkat partisipasi dalam penerapan budidaya padi organik. Kondisi tersebut dibuktikan oleh nilai t-hitung $(2,751)>$ t-tabel $(1,310)$ pada taraf nyata $\alpha$ $10 \%$. Adapun hasil analisis regresi linier sederhana tersebut dapat dirumuskan dalam 
model persamaan garis regresi sebagai berikut: $\mathrm{Y}=30,452+3,147 \mathrm{x}_{1}$. Namun demikian korelasi kedua variabel tersebut cukup kuat yang ditandai dengan hasil uji korelasi pearson dengan nilai korelasi sebesar 0,461 pada taraf nyata $\alpha 5 \%$.Nilai kooefisien regresi di atas dapat $(12 \%), 3)$ Kurangnya

dan

Tabel 4. Hasil Uji Regresi Linier Sederhana terhadap Faktor Persepsi Petani tentang Jaminan Harga Produk Pengaruhnya terhadap Tingkat Partisipasi Petani dalam Penerapan Padi Organik di Kabupaten Jember Tahun 2017

\begin{tabular}{|c|c|c|c|c|c|c|}
\hline \multirow[b]{2}{*}{ Model } & \multicolumn{2}{|c|}{ Unstandardized Coefficients } & \multicolumn{2}{|c|}{$\begin{array}{l}\text { Standardized } \\
\text { Coefficients }\end{array}$} & \multirow[b]{2}{*}{$\mathrm{t}$} & \multirow[b]{2}{*}{ Sig. } \\
\hline & $\mathrm{B}$ & Std. Error & Beta & & & \\
\hline 1 (Constant) & 30.452 & 2.826 & & & $10.777 * * *$ & .000 \\
\hline Persepsi Petani & 3.147 & 1.144 & & .461 & $2.751 *$ & .010 \\
\hline \multicolumn{6}{|c|}{ Correlations } & \\
\hline \multicolumn{6}{|c|}{ Tingkat Partisipasi } & \\
\hline \multirow[t]{3}{*}{ Tingkat Partisipasi } & Pearson Correlation & & 1 & & $.461^{*}$ & \\
\hline & Sig. (2-tailed) & & & & .010 & \\
\hline & $\mathrm{N}$ & & 30 & & 30 & \\
\hline \multirow[t]{3}{*}{ Persepsi Petani } & Pearson Correlation & & $.461^{*}$ & & 1 & \\
\hline & Sig. (2-tailed) & & .010 & & & \\
\hline & $\mathrm{N}$ & & 30 & & 30 & \\
\hline
\end{tabular}

persepsi dan keyakinan anggota kelompok tani akan adanya jaminan pemerintah atau pihak lainnya terhadap harga produk padi organik yang lebih mahal daripada padi konvensional sebesar satu satuan, maka semakin tinggi pula tingkat pertisipasi anggota kelompok tani tersebut untuk menerapkan budidaya padi organik sebesar 3,147 satuan. Secara teori bahwa antara kuat tidaknya respon dan tingkat partisipasi petani terhadap sebuah rangsangan yang menarik, pada umumnya berbanding lurus. Namun demikian fakta di lapangan menunjukkan bahwa pasar hasil produksi padi organik selama ini juga belum ada jaminan pemerintah selaku pemangku kepentingan, sehingga harga ouput tidak berbeda jauh dengan produk padi konvensional. Oleh karena itu, penyuluh pertanian lapangan (PPL) dituntut bekerja keras untuk mendampingi kelompok tani dan anggotanya agar semakin responsif dan partisipatif terhadap upaya penerapan budidaya padi organik yang mendesak untuk dilaksanakan di lapangan guna mengembalikan kesuburan tanah secara ekologis, mudah diterima dan melindungi kesehatan dan pangan masyarakat secara sosiologis, dan lebih mensejahteraan petani dan keluarganya secara ekonomis dan berkeadilan (Musriyah, 2016).

Hasil penelitian Hadi et al. (2017) mengungkapkan bahwa faktor frekuensi kunjungan PPL ke lapangan ternyata berpengaruh nyata pada tinggi rendahnya respon petani terhadap usahatani padi organik. Hal ini berarti semakin sering PPL berkunjung ke lapangan untuk memberikan sosialisasi, motivasi, pengetahuan, informasi pasar, dan pendampingan kepada para petani, maka respon petani terhadap usahatani padi organik cenderung akan semakin kuat. Fenomena ini seiring dengan hasil penelitian Rukka, Buhaerah dan Sunaryo (2006) di Kabupaten Gowa dan hasil penelitian Suprapto (2010) di Kabupaten Sragen yang menunjukkan bahwa ada pengaruh nyata variabel intensitas kunjungan penyuluh ke lapangan terhadap penggunaan pupuk organik pada padi sawah dan peningkatan pendapatan petani. Seringnya PPL ke lapangan 
terutama bagi petani padi konvensional akan dapat merubah persepsi petani, menambah motivasi dan mendorong sikap, meningkatkan keterampilan dan pengetahuan serta memperkuat tingkat partisipasi petani tersebut untuk bergeser dari sistem semula yang diterapkan. Bahkan pengaruh bagi para petani padi organik akan semakin menambah keterampilan dan pengetahuannya tentang sistem pertanian organik dan manfaat yang akan ditimbulkannya.

Pendidikan Tinggi $\quad-\quad$ Kementrian Ristekdikti Republk Indonesia yang telah mensupport dana penelitian melalui Skim Penelitian Produk Terapan (PPT) Tahun Anggaran 2017. Dengan dukungan dana hibah ini, maka penulis dapat melakukan penelitian dan publikasi ilmiah melalui kegiatan seminar nasional dan jurnal berkala ilmiah nasional yaitu Jurnal Penyuluhan IPB.

\section{Kesimpulan}

Peran kelompok tani dalam mendorong anggotanya untuk menerapkan budidaya padi organik tergolong kurang kuat (kurang berhasil), dan jika dikonversi ke dalam satuan persentse maka rata-rata tingkat keberhasilan kelompok tani mencapai $57,33 \%$ dimana sebagian besar $(52 \%)$ responden menyatakan cukup berhasil, sebagian lagi (36\%) menyatakan sudah berhasil dan sebagian lainnya menyatakan gagal. Faktor penyebab tingkat kegagalan tersebut diakibatkan hal-hal sebagai berikut: 1) Minimnya informasi terkait sistem pertanian organik dari PPL setempat dan bukti yang nyata $(24 \%), 2)$ Rendahnya tingkat kesadaran petani, kurang sabar dan tidak mau ruwet menunjukkan bahwa semakin kuat peran serta penyuluh kelompok tani dalam memberi informasi terkait SPO (16\%), 4) Petani masih kurang menerima fasilitas dari pemerintah tentang SPO (20\%), 5) Letak Demplot kurang tepat (masih terkontaminasi dengan konvensional $(8 \%)$, dan 6) Jaminan pasar produk organik belum meyakinkan para petani $(20 \%)$. Sementara itu, faktor persepsi petani terhadap jaminan harga produk padi organik berpengaruh nyata terhadap tingkat partisipasi petani terhadap penerapan budidaya padi organik pada taraf nyata $\alpha 10 \%$. Hal ini ditunjukkan oleh hasil analisis regresi sederhana dimana nilai t-hitung $(2,751)>t$-tabel $(1,310)$ dengan nilai korelasi sebesar 0,461 pada taraf nyata $\alpha 5 \%$.

\section{Ucapan Terima Kasih}

Terima kasih penulis ucapkan kepada Direktora Riset dan Pengabdian kepada Masyarakat -Direktorat Jenderal

\section{Daftar Pustaka}

Dinas Pertanian Kabupaten Jember, 2012. Potensi Pengembangan Pertanian Organik di Kabupaten Jember. 18 March 2012 21:16 Media Online Bhirawa. Diunduh Tanggal 10 September 2017.

Ediyanto, R.A., dan Hadi, S., 2016. Respon Petani Terhadap Padi Organik di Desa Seruni Kecamatan Jenggawah kabupaten Jember. Saintek. 13 (1): Hal. 29 - 35.

Hadi, S., Akhmadi, A.N., dan Prayuginingsih, H., 2017. Tingkat Respon dan Partisipasi Petani Terhadap Budidaya Padi Organik di Kabupaten Jember. Prosiding Seminar Nasional Fakultas Pertanian UGM pada tanggal 23 September 2017. ISSN: 2442-7314.

Hindarti, S., Muhaimin, W., dan Soemarno, 2012. Analisis Respon Petani Apel Terhadap Penerapan Sistem Pertanian Organik di Bumiaji Kota Batu. Program Magister Pengelolaan Sumberdaya Lingkungan, Program Pascasarjana, Universitas Brawijaya, Malang. Dalam Jurnal Wacana. 15 (2) Hal: $1-11$.

IFOAM, 2009. Basic Standard of Organic Agriculture ang Food Processing. International Federation of Organic Agriculture Movement. Tholey- 
Theley. $24 \mathrm{p}$.

Indrawati, K, 2013. Analisis Pendapatan dan Motivasi Petani serta Prospek Pengembangan Usahatani Padi Organik di Desa Rowosari Kecamatan Sumberjambe Kabupaten Jember. Jurusan Sosial Ekonomi/Agribisnis Fakultas Pertanian Universitas Jember. repository.unej.ac.id/bitstream.

Diakases Pada tanggal 10 September 2017.

Mc. Deeck, 2007. Organic Farming System. http://id.shvoong.com. Diunduh pada tanggal 9 September 2017 pada pukul 19.15.

Mentan RI, 2013. Peraturan Menteri Pertanian RI Nomor 64 Tahun 2013 tentang Sistem Pertanian Organik.http//:deptan.go.id Diakses tanggal 15 Maret 2016.

Murtiyanto, 2011. Partisipasi Masyarakat. http://bagasaskara.wordpress.com.

Diakses Pada tanggal 08 September 2017.

Musriyah, 2016. Pertanian Organik sebagai Sistem Berkelanjutan. http://distanprovinsibali. com. diakses pada tanggal 01 April 2016

Nuraini, C., Darwanto, D.H., Masyhuri, dan Jamhari, 2016. Model Kelembagaan pada Agribisnis Padi Organik Kabupaten Tasikmalaya. Jurnal Agraris. 2 (1): Hal. 10 - 16.

Nurmala, S., I., 2011. Analisis Ekonomi Usahatani Padi Semi Organik dan Anorganik pada Petani Penggarap (Studi Kasus: Desa Ciburuy dan Desa Cisalada, Kecamatan Cigombong, Kabupaten Bogor). http://repository.ipb.ac.id. Diakses pada tanggal 25 Agustus 2017.

Nuryanti, S., dan Swastika, D.K.S., 2011. Peran Kelompok Tani Dalam Penerapan Teknologi Pertanian. Jurnal Forum Penelitian Agro Ekonomi. 29 (2): Hal. 115- 128.

Permana, I., 2016. Peran Kelompok Tani Sayuran Organik terhadap Pengembangan Ekonomi Lokal
Kabupaten Semarang (Studi Kasus di Desa Batur Kecamatan Getasan). Skripsi pada Fakultas Ekonomika dan Bisnis Universitas Diponogoro Semarang. eprints.undip.ac.id. Diakses Tanggal 17 September 2017.

Rukka, H., Buhaerah dan Sunaryo, 2006. Hubungan Karakteristik Petani dnga Respon Petani terhadap Penggunaan Pupuk Organik pada Padi Sawah (Oryza sativa L.) di Kabupaten Gowa dalam Jurnal Agrisistem, Juni 2006, Vol 2 No. 1 ISSN 1858-4330

Santoso, N., K, Hartono, G., Nuswantara, B., 2012. Analisis Komparasi Usahatani Padi Organik dan An Organik di Kecamatan Sambirejo Kabupaten Sragen dalam Jurnal AGRIC. Vol. 24 No. 01 Juli Tahun 2012. Hal 63-80.

Singarimbun, M. dan Effendi, S., 1987. Metode Penelitian Survai. Jakarta (ID): LP3ES.

Sitopu, R., Fausia, L., dan Jufri M., 2014. Partisipasi Petani dalam Penerapan Usahatani Padi Organik (Studi Kasus: Desa Lubuk Bayas Kecamatan Perbaungan Kabupaten Serdang Bedagai). Journal on Social Economic of Agricultural and Agribussiness. 3 (4): Hal. 1 - 11.

Suprapto, E., 2010. Analisis Faktor-faktor yang mempengaruhi Usahatani Padi Organik Di kabupaten Sragen. http://www.Jurnalpenelitianagribisnis IB.com. Diakses pada tanggal 15 September 2017.

Tandisau, P., dan Herniwati, 2009. Prospek Pengembangan Pertanian Organik di Sulawesi Selatan. Balai Pengkajian Teknologi Pertanian Sulawesi Selatan. Dalam Prosiding Seminar Nasional Serealia 2009. ISBN :978-979-894027-9.

Widnyana, I., K., 2011. Upaya Meningkatkan pendapatan Petani Melalui Pendampingan Penerapan Ipteks Peningkatan Produktivitas Padi Berbasis Organik (P3BO). Fakultas 
Jurnal Penyuluhan, September 2019, Vol. 15 No. 2

Pertanian Universitas Mahasaraswati

Denpasar. Dalam Majalah Aplikasi

Ipteks Ngayah, 2(2), 2011, 35-43. 